\title{
Chagas disease is associated with a poor outcome at 1-year follow-up after cardiac resynchronization therapy
}

\author{
(iD) Luiz Carlos Santana Passos ${ }^{1}$ \\ (iD) Rodrigo Morel Vieira de Melo' \\ (iD) Yasmin Menezes Lira ${ }^{1}$ \\ Natalia Ferreira Cardoso de Oliveira ${ }^{1}$ \\ (D) Thiago Trindade ${ }^{1}$ \\ (D) William Carvalho' \\ (iD) Alexsandro Fagundes ${ }^{1}$
}

1. Hospital Ana Nery, Universidade Federal da Bahia, Salvador, BA, Brasil.

http://dx.doi.org/10.1590/1806-9282.65.11.1391

\section{SUMMARY}

BACKGROUND: Cardiac resynchronization therapy (CRT) is a therapeutic modality for patients with heart failure (HF). The effectiveness of this treatment for event reduction is based on clinical trials where the population of patients with Chagas' disease (DC) is underrepresented.

OBJECTIVE: To evaluate the prognosis after CRT of a population in which CD is an endemic cause of HF.

METHODS: A retrospective cohort conducted between January 2015 and December 2016 that included patients with HF and left ventricular ejection fraction (LVEF) of less than 35\% and undergoing CRT. Clinical and demographic data were collected to search for predictors for the combined outcome of death or hospitalization for HF at one year after CRT implantation.

RESULTS: Fifty-four patients were evaluated, and 13 (24.1\%) presented CD as the etiology of HF. The mean LVEF was $26.2 \pm 6.1 \%$, and 36 (66.7\%) patients presented functional class III or IV HF. After the mean follow-up of $15( \pm 6,9)$ months, $17(32.1 \%)$ patients presented the combined outcome. In the univariate analysis, CD was associated with the combined event when compared to other etiologies of $H F, 8(47 \%)$ vs. 9 (13,5\%), RR: 3,91 Cl: 1,46-10,45, $p=0,007$, as well as lower values of LVEF. In the multivariate analysis, CD and LVEF remained independent risk factors for the combined outcome.

CONCLUSION: In a population of HF patients undergoing CRT, CD was independently associated with mortality and hospitalization for HF. KEYWORDS: Heart Failure. Chagas Disease. Cardiac Resynchronization Therapy.

\section{INTRODUCTION}

Heart failure (HF) is the common final stage of most diseases that affect the heart and one of the most important current clinical challenges in health'. Currently, there is a prevalence of 23 million people worldwide, and almost 300,000 deaths are attributed to HF every year ${ }^{2,3}$. Data from Datasus have demonstrated that, in 2012 alone, there were 26,694 deaths due to $\mathrm{HF}$ in Brasil. In association with that, $50 \%$ of all hospitalized patients with that diagnosis are readmitted within 90 days after hospital discharge, and the readmission becomes one of the major risk factors for death in this syndrome ${ }^{4}$.

Patients with advanced HF may have left ventricular systolic dysfunction and cardiac dyssynchrony ${ }^{5}$. 
Cardiac resynchronization therapy (CRT), by means of multisite pacing, can restore cardiac synchrony, reducing the hospitalization rate of these patients ${ }^{2}$. Thus, TRC can be used as an adjuvant therapy to pharmacological treatment, reducing the morbidity and mortality of patients with advanced $\mathrm{HF}^{6}$.

Chagas disease (CD) produces progressive myocardial damage and later results in Chronic Chagas Cardiomyopathy and is the third cause of $\mathrm{HF}$ in Brasil and the number one non-ischemic cause in Latin America ${ }^{7}$. Knowing that some of the main mechanisms of death in CD are the progression to advanced HF and left ventricular systolic dysfunction, the CRT is an attractive option, in addition to clinical therapy, to improve the prognosis of these patients $^{8,9}$. Due to the high prevalence of $C D$ in Latin America and its emergence in non-endemic areas, such as the United States, due to the process of globalization and migratory flows, more studies are needed directly relating TRC with Chagas disease $^{6,10}$.

Currently, there are studies that address CRT in patients with heart failure, especially those affected by ischemic etiology. However, when we look at CRT in patients with HF due to Chagas disease in previous works, such as guidelines and large trials, there are no clear results or, often, the etiology is not contemplated in the study population. Thus, the present study aims to evaluate the prognosis of the TRC in a population in which Chagas disease is considered endemic.

\section{METHODS}

\section{Population}

This is a retrospective cohort study whose recruitment was conducted between January 2015 and December 2016. We consecutively included outpatients who underwent CRT, monitored by the heart failure unit of the Ana Nery Hospital of the Federal University of Bahia. All patients were over 18 years old, had symptoms of advanced heart failure, with left ventricular ejection fraction (LVEF) $\leq 35 \%$, with QRS complex duration $>150 \mathrm{~ms}$.

Chagas disease was confirmed by specific serological tests. We excluded from the study patients with prior use or indication for combined therapy with implantable cardioverter-defibrillator (ICD), patients who still had no investigation of the etiology of the heart disease, with chronic inflammatory systemic diseases, malignant neoplasm under treatment, who refused to undergo the procedure, or who declined to give informed consent.

\section{Follow-up and Outcomes}

The patients were followed-up on an outpatient basis at the institution after hospital discharge. Those who did not return after one year of the TRC implantation were contacted by phone. As an outcome measure, we used the combined event of hospitalization due to decompensated heart failure and death from all causes. If patients presented more than one event, we considered only the first.

\section{Ethics Committee}

The Research Ethics Committee of the Ana Nery Hospital - Salvador (BA) approved the study, and all procedures were performed per the Declaration of Helsinki.

\section{Statistical analysis}

The Kolmogorov-Smirnov test was used to verify the normal distribution of continuous variables. Variables with normal distribution were described by means and standard deviations and compared by Student's t-test. Categorical variables were compared using the chi-square test. The Log-Rank test was used to compare the time distribution for the primary outcome. A p-value $<0.05$ was considered statistically significant. We used the Cox model for multivariate analysis, including variables likely to be associated with the outcome. We used the stepwise variable entry method, with an entry criterion of a p-value $=0.15$ and as the exclusion criterion a $\mathrm{p}$-value $=0.25$. The Statistical Package for Social Sciences (SPSS) software version 20.0 was used to analyze all data.

\section{RESULTS}

During the recruitment period, 61 patients were evaluated for CRT implantation. Of these, four were excluded for having an indication for ICD implantation and three for not yet present investigation of the HF etiology. A total of 54 patients were included in the final study population. CD was the most frequent etiology of HF, along with ischemic and idiopathic etiologies, 13 (24.1\%) each.

The Chagas and non-Chagas groups were balanced for the variables: male sex 4 (30.7\%) vs. 27 (65.9\%), 
age 64.7 years $( \pm 9.3)$ vs 61.6 years $( \pm 13.0)$, LVEF $27 \%$ $( \pm 5.3)$ vs $26.1 \%( \pm 6.4)$, FC III-IV, 10 (76.9\%) vs. 26 (63.4\%), respectively. Demographic data are described in Table I.

After a mean follow-up of $15( \pm 6.9)$ months, 17 (31.4\%) patients presented the combined outcome of death or hospitalization due to HF, 8 of which (47\%) had CD (Table II). In the univariate analysis, CD was associated with the combined outcome when compared to other HF etiologies: 8 (47\%) vs. 9 (13.5\%), RR: $3.91 \mathrm{CI} ; 1.46-10.45, \mathrm{p}=0.007$. The ejection fraction of the left ventricle was also inversely associated with the combined outcome, RR: 0.90 CI; 0.83-0.98, $p=0.014$ (Table III).

After multivariate analysis, including the variables for Chagas disease and LVEF, both remained

TABLE 1. DEMOGRAPHIC CHARACTERISTICS

\begin{tabular}{l|l|l|l|l} 
& & Chagas & Non-Chagas & $\mathrm{P}^{*}$ \\
\hline Age, $($ Mean + SD) & $\mathrm{n}=54$ & $\mathrm{n}=13$ & $\mathrm{n}=41$ & \\
\hline Male, $\mathrm{n}(\%)$ & $62.3(+12.2)$ & $64.7(+9.3)$ & $61.6(+13.0)$ & 0.169 \\
\hline FC III or IV, $\mathrm{n}(\%)$ & $31(57.4 \%)$ & $4(30.7 \%)$ & $27(65.9 \%)$ & 0.051 \\
\hline LVEF (Mean + SD) & $36(66.7 \%)$ & $10(76.9 \%)$ & $26(63.4 \%)$ & 0.468 \\
\hline Diabetes, $\mathrm{n}(\%)$ & $26.2(+6.1)$ & $27.0(+5.3)$ & $26.1(+6.4)$ & 0.179 \\
\hline Atrial fibrillation, $\mathrm{n}(\%)$ & $14(25.9 \%)$ & $2(15.3 \%)$ & $12(29.2 \%)$ & 0.475 \\
\hline Prior pacemaker, $\mathrm{n}(\%)$ & $4(7.4 \%)$ & $0(0 \%)$ & $4(9.7 \%)$ & 0.562 \\
\hline HF etiology & $9(16.7 \%)$ & $4(30.8 \%)$ & $5(12.2 \%)$ & 0.195 \\
\hline Ischemic, $\mathrm{n}(\%)$ & & & & \\
\hline Idiopathic, $\mathrm{n}(\%)$ & & & $13(24.1 \%)$ & \\
\hline Hypertensive, $\mathrm{n}(\%)$ & & & $13(24.1 \%)$ & \\
\hline Valvular, $\mathrm{n}(\%)$ & & & $9(16.7 \%)$ & \\
\hline ARB or ACE inhibitors & & & $4(7.4 \%)$ & \\
\hline Beta-blocker & $31(57.4 \%)$ & $8(61.5 \%)$ & $23(56.1 \%)$ & 1.0 \\
\hline Spironolactone & $28(51.9 \%)$ & $6(46.2 \%)$ & $22(53.7 \%)$ & 0.75 \\
\hline FC $=$ New York & $32(59.3 \%)$ & $8(61.5 \%)$ & $24(58.5 \%)$ & 1.0 \\
\hline
\end{tabular}

$F C=$ New York Heart Association functional class $; \mathrm{LVEF}=\mathrm{Left}$ ventricle ejection fraction; $\mathrm{CRI}=$ Chronic renal insufficiency; $\mathrm{HF}=\mathrm{Heart}$ failure; $\mathrm{ACE}=$ Angiotensin-converting enzyme; $\mathrm{ARB}=$ Angiotensin receptor blockers

* Comparison between Chagas and Non-Chagas.

TABLE II. DESCRIPTION OF THE OUTCOMES

\begin{tabular}{c|l|l|l|l} 
& $\mathrm{n}=54$ & $\begin{array}{l}\text { CHAGAS } \\
\mathrm{n}=13\end{array}$ & $\begin{array}{l}\text { NON-CHAGAS } \\
\mathrm{n}=41\end{array}$ & $\mathrm{P}$ \\
\hline Combined outcome, $\mathrm{n}(\%)$ & $17(31.4 \%)$ & $8(61.5 \%)$ & $9(21.9 \%)$ & 0.007 \\
\hline Death, $\mathrm{n}(\%)$ & $5(9.2 \%)$ & $3(23.0 \%)$ & $2(4 \%)$ & 0.620 \\
\hline Hospitalization due to HF, $\mathrm{n}(\%)$ & $12(22.2 \%)$ & $5(38.5 \%)$ & $7(17.0 \%)$ & 0.620 \\
\hline
\end{tabular}

$\mathrm{HF}=$ Heart failure.

TABLE III. UNIVARIATE AND MULTIVARIATE ANALYSIS OF PREDICTORS FOR THE COMBINED OUTCOME

\begin{tabular}{|c|c|c|c|c|}
\hline & \multicolumn{2}{|l|}{ Univariate Analysis } & \multicolumn{2}{|c|}{ Multivariate Analysis } \\
\hline & $\mathrm{RR}(95 \% \mathrm{Cl})$ & $P$ & $\mathrm{RR}(95 \% \mathrm{Cl})$ & $P$ \\
\hline Age, (years) & $0.99(0.96-1.03)$ & 0.68 & - & - \\
\hline Male & $1.38(0.49-3.87)$ & 0.53 & - & - \\
\hline FC III or IV & $1.36(0.38-4.81)$ & 0.64 & - & - \\
\hline $\operatorname{LVEF}(\%)$ & $0.90(0.82-0.98)$ & 0.01 & $0.88(0.81-0.97)$ & $<0.01$ \\
\hline CRI & $1.08(0.14-8.59)$ & 0.94 & - & - \\
\hline Atrial fibrillation & $1.86(0.23-15.34)$ & 0.56 & - & - \\
\hline Chagas disease & $3.91(1.46-10.45)$ & $<0.01$ & $4.40(1.48-13.12)$ & $<0.01$ \\
\hline Diabetes & $1.30(0.36-4.63)$ & 0.68 & - & - \\
\hline
\end{tabular}

$\mathrm{FC}=$ New York Heart Association functional class $; \mathrm{LVEF}=$ Left ventricle ejection fraction; $C R I=$ Chronic renal insufficiency. 
independent risk factors for the combined outcome: Chagas disease, RR 4.40 CI 1.48 to $13.12, \mathrm{P}=0.008$, LVEF, RR 0.88 CI 0.81 to $0.97, \mathrm{P}=0.008$.

\section{DISCUSSION}

The study sample had $24.1 \%$ of patients with HF secondary to $\mathrm{CD}$, a relatively good representation of the condition. Upon comparing the Chagas disease group with other etiologies, we found a similarity in the predominance of FC III-IV, as well as in the average age and LVEF. After a mean follow-up of 15 months $( \pm 6.9), 17$ (31.4\%) patients presented the combined outcome of death or hospitalization due to heart failure, 8 of which (47\%) had CD. In the univariate analysis, CD and lower values of LVEF were associated with the combined outcome of death or hospitalization due to heart failure. After the multivariate analysis of predictors, CD and LVEF remained independent risk factors for the combined outcome.

The study showed a high rate of cardiovascular events when compared with the average follow-up time. In studies such as those by Cleland et al. ${ }^{8}$ and Moss et al. ${ }^{6}$, the follow-up time required for the prevalence of cardiovascular events versus the follow-up period to be similar to that of the present study was 2.5 and 4.5 years, respectively.

There are risk factors in the study sample that may justify the high rate of cardiovascular events in short follow-up time. The low socioeconomic and educational level of this population favors poor medication adherence, with greater difficulty of establishing optimized clinical treatment, thus increasing the incidence of negative outcomes ${ }^{1}$. In our sample, the rate of non-use of beta-blockers, spironolactone, ARB or ACE inhibitors was little more than half in both groups, i.e., Chagas and non-Chagas' Disease. In addition, the population is severe, with a predominance of FC III-IV and $\leq 35 \%$ LVEF; previous studies have found that the survival rate of these patients is only $16 \%$ at 36 months $^{2}$.

According to the Brazilian Guideline of Implantable Electronic Cardiac Devices ${ }^{11}$, class I recommendations for implantation of a cardiac resynchronizer are: patients with LVEF $<35 \%$, sinus rhythm, HF with FC III-IV, despite optimal drug treatment and with QRS $>150$ ms or 120-150 ms and proof of dyssynchrony by imaging method. The studies that have led to this consensus, such as the Miracle ${ }^{12}$ and the Companion ${ }^{13}$, had as a sample HF patients with functional class III or IV, QRS $>120 \mathrm{~ms}$, and ischemic heart disease as the main etiology of the heart failure. In both studies, CD was under-represented or not mentioned as a possible etiology of HF. Unlike in our study, in which, despite having a similar population regarding the FC and QRS value criteria, Chagas disease was well represented and considered as an independent predictor of death or hospitalization due to heart failure after CRT.

Mortality due to CD is intimately linked to the degree of myocardial involvement in the course of the disease ${ }^{2}$. Pathological studies on Chagas disease have found sites of prominent myocardial fibrosis. After imaging studies by magnetic resonance, they found that the areas most affected by the fibrosis are the apex of the left ventricle and post-lateral sites $^{14,15}$. Bleeker et al. ${ }^{16}$ showed that patients with scar tissue in the post-lateral wall do not respond to CRT, even in the presence of dyssynchrony in the left ventricle.

Sudden cardiac death is the main cause of death in the CD and is considered one of the most common phenomena of this pathology, with a prevalence of 55-65\%. Thus, ICD implantation associated with optimal drug treatment is a strategy for the primary and secondary prevention of sudden cardiac death in this disease ${ }^{14,17}$. Sales et al. ${ }^{18}$ demonstrated the null effect of resynchronization therapy on the incidence of sudden death.

The present study presents some limitations due

\section{FIGURE 1}

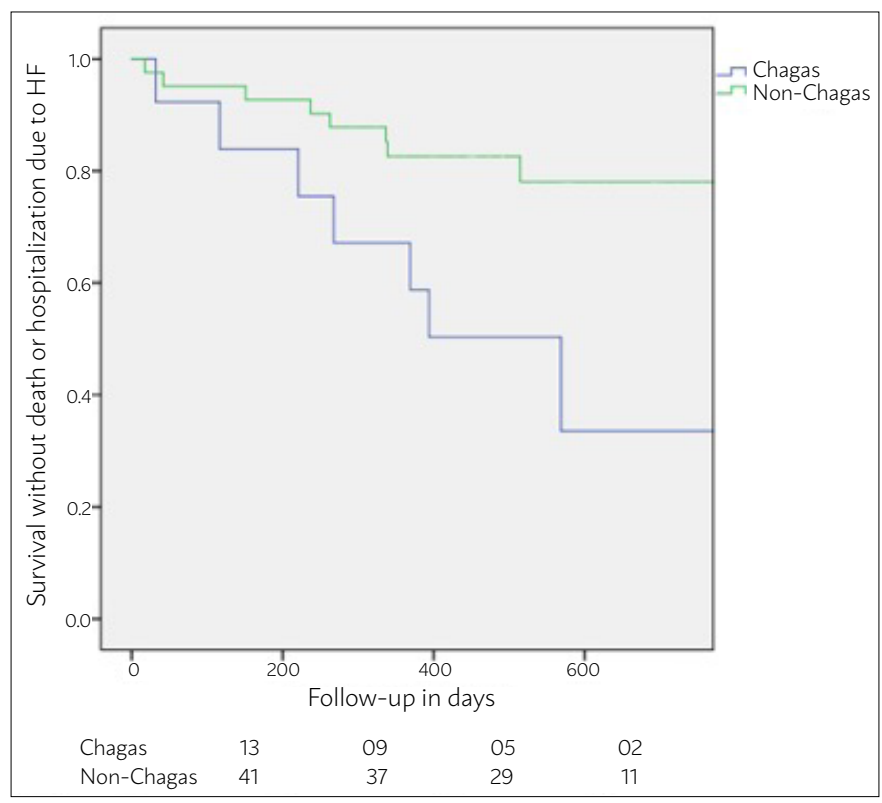


to its unicentric retrospective cohort design, in which the variables were collected by means of electronic records, subjecting the work the biases inherent to this design. Thus, it was not possible to evaluate the degree of cardiac dyssynchrony by ECHO before the CRT, not even measures related to the systolic and diastolic diameter of the left ventricle and LVEF after the resynchronization therapy. Incomplete ECG data did not allow us to analyze the prevalence of right branch block in patients with Chagas disease, because, when present, it decreases the success rate of CRT. The absence of data relating to the magnetic resonance imaging prevented the analysis of the extent and location of myocardial fibrosis in patients submitted to this procedure, which may have interfered with the effectiveness of the therapy.
After analysis and discussion of the results found in this article, we confirmed the need for more prospective studies that address the combined outcome of death or hospitalization due to HF in patients with CD undergoing CRT. These studies will be important to identify risk predictors for this outcome and, consequently, therapeutic measures that involve such factors to enable a better prognosis for HF patients of Chagas etiology.

\section{CONCLUSION}

In a population of HF patients who underwent CRT, among which the Chagas etiology is frequent, Chagas cardiomyopathy was associated with a worse prognosis in the short-term follow-up.

\section{RESUMO}

INTRODUÇÃO: A terapia de ressincronização cardíaca (TRC) é uma modalidade terapêutica para pacientes com insuficiência cardíaca (IC). A eficácia desse tratamento para redução de eventos baseia-se em ensaios clínicos em que a população de pacientes com doença de Chagas (DC) é sub-representada.

OBJETIVO: Avaliar o prognóstico após TRC em uma população em que a DC é uma causa frequente de IC.

MÉTODOS: Coorte retrospectiva realizada entre janeiro de 2015 e dezembro de 2016, sendo incluídos pacientes portadores de IC com fração de ejeção do ventrículo esquerdo (Feve) menor que 35\% e submetidos à TRC. Os dados clínicos e demográficos foram coletados para pesquisa de preditores para o desfecho combinado de morte ou internação por IC após implante da TRC.

RESULTADOS: Foram avaliados 54 pacientes, dos quais 13 (24,1\%) apresentavam a DC como etiologia da IC. A Feve média foi de 26,2\% $( \pm 6,1)$ e $36(66,7 \%)$ pacientes apresentavam classe funcional de IC III ou IV. Após o seguimento médio de 15 meses, 17 (32,1\%) pacientes apresentaram o desfecho combinado. Na análise univariada, a DC esteve associada ao evento combinado quando comparada a outras etiologias de IC, 8 (47\%) vs 9 (13,5\%), RR:3,91 IC: 1,46-10,45, p=0,007, assim como valores mais baixos da Feve. Na análise multivariada, a DC e a Feve permaneceram como fatores de risco independentes para o desfecho combinado.

CONCLUSÃo: Em uma população de pacientes com IC submetidos à TRC, a doença de Chagas esteve independentemente associada à mortalidade e internação por insuficiência cardíaca no seguimento de 15 meses.

PALAVRAS-CHAVE: Insuficiência cardíaca. Doença de Chagas. Terapia de ressincronização cardíaca. 


\section{REFERENCES}

1. Roger VL. Epidemiology of heart failure. Circ Res. 2013;113(6):646-59.

2. Araújo EF, Chamlian EG, Peroni AP, Pereira WL, Gandra SM, Rivetti LA. Cardiac resynchronization therapy in patients with chronic Chagas cardiomyopathy: long-term follow up. Rev Bras Cir Cardiovasc. 2014;29(1):31-6.

3. Bui AL, Horwich TB, Fonarow GC. Epidemiology and risk profile of heart failure. Nat Rev Cardiol. 2011;8(1):30-41.

4. Albuquerque DC, Souza Neto JD, Bacal F, Rohde LE, Bernardez-Pereira S, Berwanger O; Investigadores Estudo BREATHE, et al. I Brazilian registry of heart failure: - clinical aspects, care quality and hospitalization outcomes. Arq Bras Cardiol. 2007;104(6):433-42.

5. St. John Sutton MG, Plappert T, Abraham WT, Smith AL, DeLurgio DB, Leon AR; Multicenter InSync Randomized Clinical Evaluation (MIRACLE) Study Group, et al. Effect of cardiac resynchronization therapy on left ventricular size and function in chronic heart failure. Circulation. 2003;107(15):1985-90.

6. Moss AJ, Hall WJ, Cannom DS, Klein H, Brown MW, Daubert JP, et al. Cardiac-resynchronization therapy for the prevention of heart-failure events. N Engl J Med. 2009;361(14):1329-38.

7. Bocchi EA, Braga FG, Ferreira SM, Rohde LE, Oliveira WA, Almeida DR, et al.; Sociedade Brasileira de Cardiologia. III Diretriz brasileira de insuficiência cardíaca crônica. Arq Bras Cardiol. 2009;93(1 supl.1):3-70.

8. Cleland JGF, Daubert JC, Erdmann E, Freemantle N, Gras D, Kappenberger $L$, et al. The effect of cardiac resynchronization on morbidity and mortality in heart failure. N Engl J Med. 2005;352(15):1539-49.

9. St. John Sutton MG, Plappert T, Abraham WT, Smith AL, DeLurgio DB, Leon AR; Multicenter InSync Randomized Clinical Evaluation (MIRACLE) Study Group, et al. Effect of cardiac resynchronization therapy on left ventricular size and function in chronic heart failure. Circulation. 2003;107(15):1985-90.
10. Madias C, Trohman RG. Cardiac resynchronization therapy: the state of the art. Expert Rev Cardiovasc Ther. 2014;12(5):573-87.

11. Martinelli Filho M, Zimerman LI, Lorga AM, Vasconcelos JTM, Lorga Filho AM, Fagundes AA, et al. Guidelines for implantable electronic cardiac devices of the Brazilian Society of Cardiology. Arq Bras Cardiol. 2007;89(6):e210-38.

12. Abraham WT, Fisher WG, Smith AL, Delurgio DB, Leon AR, Loh E, et al. Cardiac resynchronization in chronic heart failure. N Engl ] Med. 2002;346(24):1845-53.

13. Bristow MR, Saxon LA, Boehmer |, Krueger S, Kass DA, De Marco T, et al. Cardiac-resynchronization therapy with or without an implantable defibrillator in advanced chronic heart failure. N Engl J Med. 2004;350(21):2140-50.

14. Duarte JOP, Magalhães LP, Santana OO, Silva LB, Simões M, Azevedo DO, et al. Prevalência e valor prognóstico da dissincronia ventricular na cardiomiopatia chagásica. Arq Bras Cardiol. 2011;96(4):300-6.

15. Rassi A Jr, Rassi SG, Rassi A. Sudden death in Chagas' disease. Arq Bras Cardiol. 2001;76(1):75-96.

16. Bleeker GB, Kaandorp TA, Lamb HI, Boersma E, Steendijk P, Roos A, et al. Effect of posterolateral scar tissue on clinical and echocardiographic improvement after cardiac resynchronization therapy. Circulation. 2006;113(7):969-76.

17. Rochitte CE, Oliveira PF, Andrade IM, lanni BM, Parga IR, Ávila LF, et al. Myocardial delayed enhancement by magnetic resonance imaging in patients with Chagas' disease: a marker of disease severity. I Am Coll Cardiol. 2005;46(8):1553-8.

18. Sales MC, Souza LD, Frota Filho ID, Zimerman LI, Pontes MRN, Lucchese FA. Indicações de terapia de ressincronização cardíaca. Rev Soc Cardiol Rio Grande Sul. 2007;16(12):1-6. 